\title{
CHARACTERISTICS AND ASSESSMENT OF THE USEFULNESS OF SEROLOGICAL TESTS IN THE DIAGNOSTIC OF INFECTIONS CAUSED BY CORONAVIRUS SARS-CoV-2 ON THE BASIS OF AVAILABLE MANUFACTURER'S DATA AND LITERATURE REVIEW
}

\author{
CHARAKTERYSTYKA ORAZ OCENA PRZYDATNOŚCI SEROLOGICZNYCH \\ TESTÓW W DIAGNOSTYCE ZAKAŻEŃ WYWOŁYWANYCH PRZEZ KORONAWIRUS \\ SARS-CoV-2 NA PODSTAWIE DOSTĘPNYCH DANYCH PRODUCENTÓW \\ I PRZEGLĄDU PIŚMIENNICTWA
}

\author{
National Institute of Public Health - National Institute of Hygiene \\ Department of Bacteriology and Biocontamination Control
}

Narodowy Instytut Zdrowia Publicznego - Państwowy Zakład Higieny

Zakład Bakteriologii i Zwalczania Skażeń Biologicznych

\begin{abstract}
Recognized in 2019 in Wuhan, China, the new SARS-CoV-2 coronavirus is responsible for the occurrence of a global pandemic disease called COVID-19. So far, confirmation of infection is based on the detection of virus RNA in a sample taken from a person meeting the suspected case definition. However, in the laboratory diagnosis of SARS-CoV-2 infections, in addition to genetic tests, serological methods can also be used to detect specific antibodies of the IgM, IgG and IgA class produced after contact with antigens or to detect viral antigen. Currently, a number of rapid immunochromatographic, chemiluminescent and ELISA immunoassay tests developed by different manufacturers for the diagnosis of COVID-19 are available on the market. Despite this fact, so far there is no WHO or ECDC recommendations or even reliable research regarding the usefulness of serological investigations in the laboratory diagnosis of infections caused by SARS-CoV-2.
\end{abstract}

Key words: SARS-CoV-2, COVID-19, serological tests, immunochromatographic tests, chemiluminescent tests, enzyme-linked ELISA

\section{STRESZCZENIE}

Rozpoznany w 2019 roku w Wuhan w Chinach nowy koronawirus SARS-CoV-2 odpowiedzialny jest za wystąpienie światowej pandemii choroby nazwanej COVID-19. Jak do tej pory, potwierdzenie zakażenia opiera się na wykryciu RNA wirusa w próbce pobranej od osoby spełniającej kryteria definicji podejrzenia przypadku. Jednakże, w laboratoryjnej diagnostyce zakażeń SARS-CoV-2, oprócz testów genetycznych, można wykorzystywać również metody serologiczne, pozwalające na wykrycie swoistych przeciwciał klasy IgM, IgG i IgA wyprodukowanych przez organizm człowieka po kontakcie z antygenami wirusa albo też wykrywające antygen wirusa. Obecnie na rynku dostępnych jest szereg szybkich testów immunochromatograficznych, chemiluminescencyjnych oraz testów immunoenzymatycznych ELISA opracowanych przez różnych producentów, przeznaczonych do diagnostyki COVID-19. Pomimo tego, do tej pory nie ma rekomendacji WHO lub ECDC, ani nawet wiarygodnych badań dotyczących przydatności badań serologicznych wykonywanych poszczególnymi testami w laboratoryjnej diagnostyce zakażeń wywoływanych przez SARS-CoV-2.

Słowa kluczowe: SARS-CoV-2, COVID-19, testy serologiczne, testy immunochromatograficzne, testy chemiluminescencyjne, testy immunoenzymatyczne ELISA 


\section{INTRODUCTION}

Most of the previously known viruses from the Coronaviridae family cause, mainly in the winterspring season, both asymptomatic infections and infections usually manifested as mild inflammation of the upper respiratory tract. Much more serious clinical consequences are caused by two relatively recently described coronaviruses: SARS-CoV (Severe acute respiratory syndrome coronavirus) and MERS$\mathrm{CoV}$ (Middle East respiratory syndrome-related coronavirus). Mortality, in case of human infection caused by above mentioned coronaviruses, is rated respectively at 9.7 percent (SARS) and 34.5 percent (MERS). Considering both viruses it is proved, that they might have come most likely from coronaviruses infecting bats, and humans become infected most frequently from intermediate host $(1,2)$.

The outbreak of a new virus that began in 2019 in the Chinese city of Wuhan was caused by the newly described coronavirus, named SARS-CoV-2. The virus belongs to the subfamily Orthocoronavirinae in the family Coronaviridae. This is a large singlestranded RNA virus whose genome encodes four major structural proteins: nucleocapsid $(\mathrm{N})$ protein, spike (S) protein, envelope (E) protein and membrane (M) protein. The SARS-CoV-2 virion is spherical with an average diameter of 50-200 $\mathrm{nm}$. The helical nucleocapsid is enclosed by an envelope that is covered with club-shaped, long protuberance about 20 $\mathrm{nm}$ long, giving it the typical crown-like appearance, which is characteristic for coronaviruses $(\mathrm{CoV})(1,3)$.

SARS-CoV-2 has flu-like symptoms such as: fever, cough, muscle aches, sore throat, and above all as pneumonia, that can reach different forms from lighter to heavier syndromes, leading to acute respiratory distress syndrome (ARDS), metabolic acidosis, disseminated intravascular coagulation, septic shock and death. The COVID-19 incubation period is most often from 3 to 7 days, up to 14 days maximum (1).

Due to the non-specific clinical manifestations, it is not possible to diagnose SARS-CoV-2 infection without laboratory tests. According to WHO and ECDC guidelines, confirmation of SARS-CoV-2 infection is based on the detection of virus RNA in a sample taken from from a person meeting the suspected case definition $(4,5)$. In general, the material for molecular testing is a sample collected from the upper respiratory tract (nasopharyngeal and oropharyngeal swab) or lower respiratory tract (bronchoalveolar lavage, sputum, tracheal aspirate). To recognize the patient as infected with SARSCoV-2 virus, positive molecular test result should be obtained (4).

\section{WSTĘP}

Większość dotychczas poznanych wirusów z rodziny Coronaviridae wywołuje, głównie w sezonie zimowo-wiosennym, zarówno zakażenia bezobjawowe jak i zakażenia objawiające się najczęściej jako lekko przebiegające zapalenie górnych dróg oddechowych. Znacznie poważniejsze konsekwencje kliniczne wywołują dwa stosunkowo niedawno opisane koronawirusy: SARS-CoV (Severe acute respiratory syndrome coronavirus, koronawirus wywołujący ciężki zespół niewydolności oddechowej) oraz MERS-CoV (Middle East respiratory syndrome-related coronavirus, koronawirus wywołujący bliskowschodni zespół oddechowy). Śmiertelność, w przypadku zakażenia ludzi tymi wirusami, wynosi odpowiednio 9,7\% (SARS) i 34,5\% (MERS). W przypadku obu wirusów wykazano, że pochodzą one najprawdopodobniej od koronawirusów zakażających nietoperze, a człowiek zakaża się najczęściej od gospodarza pośredniego $(1,2)$.

W 2019 r. w Wuhan w Chinach doszło do wystąpienia zakażeń wywoływanych przez nowo opisany wirus z rodziny Coronaviridae, podrodziny Orthocoronavirinae, nazwany SARS-CoV-2. Jest to duży, jednoniciowy wirus RNA zbudowany z czterech białek strukturalnych: nukleokapsydu (N), białka szczytowego (S), białka otoczki (E) i białka błonowego (M). Wirion ma średnicę 50-200 nm i posiada na swojej powierzchni wypustki o długości do $20 \mathrm{~nm}$, które nadają mu kształt korony, charakterystyczny dla koronawirusów $(\mathrm{CoV})$ $(1,3)$.

Wirus SARS-CoV-2 powoduje wystąpienie objawów grypopodobnych, objawiających się jako gorączka, kaszel, bóle mięśni i gardła oraz przede wszystkim jako zapalenie płuc, które może przebiegać od postaci lekkich do ciężkich, mogących prowadzić do zespołu ostrej niewydolności oddechowej, kwasicy metabolicznej, zespołu wykrzepiania wewnątrznaczyniowego, wstrząsu i zgonu. Okres wylęgania COVID-19 wynosi najczęściej od 3 do 7 dni, maksymalnie 14 dni (1).

Ze względu na nieswoiste objawy kliniczne rozpoznanie zakażenia wirusem SARS-CoV-2 bez badań laboratoryjnych nie jest możliwe. Zgodnie z wytycznymi WHO oraz ECDC potwierdzenie zakażenia SARS-CoV-2 opiera się na wykryciu RNA wirusa w próbce pobranej od osoby spełniającej kryteria definicji podejrzenia przypadku $(4,5)$. Najczęściej do badań genetycznych pobiera się materiał $\mathrm{z}$ górnych lub dolnych dróg oddechowych - wymazy lub popłuczyny z gardła lub nosogardzieli, rzadziej materiał $z$ dolnych dróg oddechowych (płyn z płukania oskrzelowego, plwocina, aspirat przeztchawiczy). Uzyskanie wyniku dodatniego jest podstawą do uznania chorego za zakażonego wirusem SARS-CoV-2 (4). Trzeba mieć jednak na uwadze, że testy genetyczne mogą dawać wyniki ujemne we 
It should be considered that a molecular test can give false negative results in the early stages of infection and it shows maximum sensitivity after about 7 days since human contact with SARS$\mathrm{CoV}-2$ virus. There are reports that RT-PCR may give false negative results even up to the second week after infection. Several days after the onset of the first symptoms of the COVID-19 disease, the sensitivity of molecular tests gradually decreases due to a decrease in the number of virus particles in the respiratory epithelium, which may result in a false negative result $(6,7)$.

In the laboratory diagnosis of SARS-CoV-2 infections, in addition to molecular testing, serological methods can also be used to detect specific human antibodies produced after contact with viral antigens, or to detect viral antigens $(3,8,9)$.

The usefulness of serological tests that detect antibodies in the diagnosis of COVID-19 is determined by the dynamics of the humoral immune response. Detection of specific anti-SARS-CoV-2 IgM antibodies could be possible as early as 10 days after the appearance of the first clinical onset of illness, while $\operatorname{IgG}$ antibodies even later $(3,10)$. In addition, you have to keep in mind that there are large individual differences related to the intensity of the course of the disease and the state of the immune system, as well as the limited specificity of serological tests. For this reason, serological tests cannot be an alternative method to molecular testing in the diagnosis of SARS-CoV-2 infections for patients in the early stages of the disease.

However, due to the time it takes for antibody production and for the following ,serological window", serological tests may be useful in retrospective epidemiological studies to determine the prevalence of infection in the population, in screening for individuals who may have had contact with SARS- CoV-2 infected people, but they do not meet the criteria for molecular testing, or management of patients with recent history of influenza-like infection who have not been tested for coronavirus (11).

Serological methods can also be used in cases where epidemiological and clinical data strongly suggest COVID-19 infection, and the SARS-CoV-2 RT-PCR test result was negative (10).

\section{AIM}

A large number of different diagnostic test kits appearing on the market have recently introduced some information chaos, compounded by the fact that currently there are no clear recommendations on the use of specific serological tests. The aim of this work is characterization and evaluation of the wczesnych stadiach infekcji i wykazują maksymalną czułość dopiero po około 7 dniach od kontaktu człowieka z SARS-CoV-2. Istnieją nawet doniesienia, że w metodzie RT-PCR można uzyskać wyniki fałszywie ujemne nawet do drugiego tygodnia od zakażenia. Po upływie kilkunastu dni od wystapienia pierwszych objawów choroby czułość testów genetycznych stopniowo maleje z powodu spadku liczby cząstek wirusa w nabłonku dróg oddechowych co może skutkować uzyskaniem wyniku fałszywie ujemnego $(6,7)$.

W laboratoryjnej diagnostyce zakażeń SARSCoV-2, oprócz testów genetycznych, można wykorzystywać również metody serologiczne, pozwalające na wykrycie swoistych przeciwciał wytworzonych przez organizm człowieka po kontakcie $\mathrm{z}$ antygenami wirusa albo też wykrywające antygeny wirusa $(3,8,9)$.

Przydatność testów serologicznych wykrywających przeciwciała w diagnostyce COVID-19 uwarunkowana jest dynamiką pojawiania się odpowiedzi humoralnej. Wykrycie diagnostycznego poziomu swoistych przeciwciał anty-SARS-CoV-2 klasy IgM jest możliwe najwcześniej po około 10 dniach od momentu wystąpienia pierwszych objawów klinicznych zakażenia, natomiast przeciwciał klasy IgG jeszcze później $(3,10)$. Dodatkowo, trzeba pamiętać także o dużych różnicach osobniczych, związanych z intensywnością przebiegu choroby oraz stanem układu immunologicznego, a także o ograniczonej swoistości testów serologicznych. $\mathrm{Z}$ tego powodu, badania serologiczne nie mogą być alternatywą dla badań genetycznych w diagnostyce zakażeń SARS-CoV-2 u pacjentów będących w początkowej fazie choroby. Ze względu na czas potrzebny na produkcję przeciwciał i wynikające z tego „okienko serologiczne”, testy serologiczne mogą jednak znaleźć zastosowanie w retrospektywnych badaniach epidemiologicznych, mających na celu ustalenie rozpowszechnienia zakażenia w populacji, w badaniach przesiewowych osób, które mogły mieć kontakt z zakażonymi SARS-CoV-2, ale nie spełniają kryteriów wykonania badań genetycznych, czy też $\mathrm{w}$ postępowaniu z pacjentami z powikłaniami po niedawnym przebyciu infekcji grypopodobnej, którzy nie byli badani w kierunku zakażeń koronawirusami (11). Metody serologiczne mogą być też używane w przypadkach, gdy dane epidemiologiczne i kliniczne silnie sugerują zakażenie, a wykonane badanie w kierunku RNA SARS-CoV-2 dało wynik ujemny (10).

\section{CEL PRACY}

Duża liczba różnych zestawów diagnostycznych pojawiających się na rynku w ostatnim czasie wprowadza pewien chaos informacyjny potęgowany przez fakt, iż obecnie nie ma jasnych zaleceń czy też rekomendacji co do użycia konkretnych testów serologicznych. Celem prezentowanej pracy jest charakterystyka oraz ocena 
usefulness of serological tests for the diagnosis of infections caused by SARS CoV-2 virus based on available scientific publications, guidelines of the World Health Organization (WHO) and other international organizations, and information provided by manufacturers.

\section{MATERIALS AND METHODS}

At first a scientific literature review was performed. Based on search queries powered by selected keywords (i.a. antibody SARS-CoV-2, COVID-19 ELISA, COVID-19 CLIA, COVID-19 rapid test, serological investigation of SARS-CoV-2) the PubMed scientific publications database was searched. The following documents were analyzed: World Health Organization (WHO), European Center for Disease Prevention and Control (ECDC), Johns Hopkins Health Safety Center (CHS), as well as the data contained on the website of the FIND Foundation (Foundation for Innovative New Diagnostics). Based on found documents and publications in the PubMed database, a review of the serological tests for COVID-19 diagnostics developed so far in Europe and in the world was made $(4,5,8,12)$.

The results describe selected type of tests that can be used in serodiagnosis of SARS-CoV-2 virus infections, indicating their use as well as advantages and disadvantages. Examples of serological tests developed by different manufacturers or groups of scientists were also presented.

\section{RESULTS}

Figure 1 presents the dynamics of the level of RNA / antigens of the SARS-CoV-2 virus and specific IgM and IgG antibodies depending on the time since infection (13). The earliest SARS-COV-2 infection is detected by genetic and serological tests that detect viral antigens. Specific IgM antibodies for SARS-CoV-2 begin to appear at the end of the first week and IgG antibodies even one week later. It is important, that the level of antibodies, mainly in the IgG class, remains high for a long time after infection, and therefore serological tests can be successfully performed when direct testing for the presence of the virus, whether through genetic or serological tests, is not effective $(3,13,14)$. Table 1 shows the interpretation of possible configurations of RT-PCR and serological tests results (13).

Among the serological tests that detect specific antibodies, rapid "cassette" lateral flow immunochromatography (LFIA), automated chemiluminescence (CLIA) and immunoenzymatic ELISA tests have been used $(15,16)$. These methods przydatności serologicznych testów przeznaczonych do diagnostyki zakażeń wywoływanych przez koronawirus SARS CoV-2 w oparciu o dostępne publikacje naukowe, wytyczne Światowej Organizacji Zdrowia (WHO) i innych międzynarodowych organizacji oraz informacje podane przez producentów.

\section{MATERIAŁ I METODY}

Przeprowadzono przegląd piśmiennictwa naukowego. Na podstawie kwerend wyszukiwania w oparciu o wybrane słowa kluczowe (m.in. antibody SARS-CoV-2, COVID-19 ELISA, COVID-19 CLIA, COVID-19 rapid test, serological investigation of SARSCoV-2) przeszukano bazę publikacji naukowych PubMed. Przeprowadzono analizę dokumentów: Światowej Organizacji Zdrowia (WHO), Europejskiego Centrum ds. Zapobiegania i Kontroli Chorób (ECDC), Centrum Bezpieczeństwa Zdrowia Johns Hopkins (CHS), jak również danych zawartych na stronie internetowej Fundacji FIND (Foundation for Innovative New Diagnostics). Na podstawie wyszukanych dokumentów oraz publikacji w bazie PubMed dokonano przeglądu dotychczas opracowanych w Europie i na świecie testów serologicznych do diagnostyki COVID-19 $(4,5,8,12)$.

W wynikach opisano poszczególne rodzaje testów, które mogą być stosowane w serodiagnostyce zakażeń wywołanych przez wirus SARS-CoV-2 wskazując ich zastosowanie, jak również wady i zalety. Przedstawiono również przykłady testów opracowanych przez wybranych producentów i grupy naukowców.

\section{WYNIKI}

$\mathrm{Na}$ rycinie 1 przedstawiono dynamikę poziomu RNA/antygenów wirusa SARS-CoV-2 i swoistych przeciwciał klasy IgM i IgG u osób chorych w zależności od czasu jaki minął od momentu zakażenia (13). Najwcześniej zakażenie SARS-COV-2 wykrywają testy genetyczne oraz testy serologiczne wykrywające antygeny wirusów. Swoiste przeciwciała klasy IgM dla SARSCoV-2 zaczynają być produkowane pod koniec pierwszego, a przeciwciała klasy IgG pod koniec drugiego tygodnia od zakażenia. Co istotne, poziom przeciwciał klasy IgG, utrzymuje się na wysokim poziomie jeszcze przez dłuższy czas po zakażeniu i z tego powodu badania serologiczne mogą być z powodzeniem wykonywane wtedy, kiedy bezpośrednie badanie obecności wirusa czy to testami genetycznymi czy też serologicznymi jest już mało efektywne $(3,13,14)$. Tabela 1 przedstawia interpretację możliwych konfiguracji wyników badań metodą RT-qPCR i badań serologicznych (13).

Wśród testów serologicznych wykrywających swoiste przeciwciała znalazły zastosowanie szybkie, ,kasetkowe" testy immunochromatograficzne bocznego 


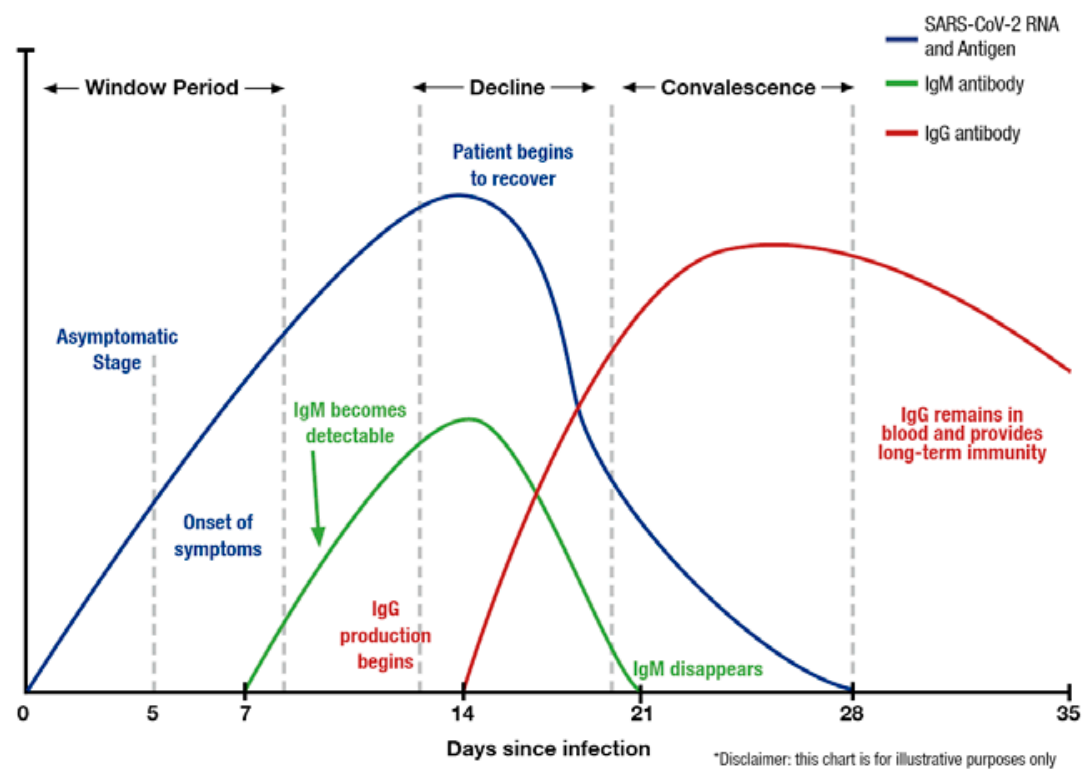

Figure 1. Dynamic of the levels of SARS-CoV RNA/antigens and specific antibodies IgM/IgG depending on the time since infection (13)

Rycina 1. Dynamika poziomu RNA/antygenów wirusa SARS-CoV-2 i swoistych przeciwciał klasy IgM i IgG w zależności od czasu jaki minął od momentu zakażenia (13)

Table I. Interpretation of possible RT-qPCR and serology COVID-19 test results configurations (13)

Tabela I. Interpretacja możliwych konfiguracji wyników badań RT-qPCR i badan serologicznych COVID-19 (13)

\begin{tabular}{|c|c|c|l|}
\hline \multicolumn{3}{|c|}{ Test results } & \multicolumn{2}{c}{ Interpretation } \\
\cline { 1 - 3 } RT-qPCR & IgM & IgG & \\
\cline { 1 - 3 }+ & - & - & $\begin{array}{l}\text { „Serological window”, when the infected organism has not yet managed to produce } \\
\text { antibodies }\end{array}$ \\
\cline { 1 - 3 }+ & + & - & Early stage of infection caused by SARS-CoV-2 virus \\
\hline+ & + & + & Active phase of infection caused by SARS-CoV-2 virus \\
\hline+ & - & + & Late or recurrent stage of infection caused by SARS-CoV-2 virus \\
\hline- & + & - & $\begin{array}{l}\text { Early stage of infection caused by SARS-CoV-2 virus. RT-qPCR result may be } \\
\text { false-negative }\end{array}$ \\
\hline- & - & + & Late stage of an infection or patient has recovered \\
\hline- & + & + & Recovery stage of an infection or RT-qPCR result may be false-negative \\
\hline
\end{tabular}

detect immunoglobulins $\mathrm{M}(\mathrm{IgM})$ and $\mathrm{IgG}$, sometimes also $\operatorname{IgA}$, produced by individuals in response to SARS-CoV-2 infection.

Continuously, the research in the field of technology and production of new diagnostic kits is carried out in foreign and domestic research centers, as well as in companies producing diagnostic tests (3). It should be taken into consideration that some of the available tests can only be used in scientific research (RUO, research use only) and only those certified (CE-IVD) can be used in routine diagnosis. Most tests have been developed in China, Republic of Korea and the USA. Diagnostic sets are also produced by companies in other countries $(3,12)$. przepływu (LFIA), zautomatyzowane testy chemiluminescencyjne (CLIA) oraz test immunoenzymatyczny ELISA $(15,16)$. Metody te umożliwiają wykrywanie immunoglobulin M (IgM) oraz IgG, czasami również IgA, wytwarzanych u osób w odpowiedzi na zakażenie wirusem SARS-CoV-2. Nieprzerwanie, w zagranicznych i krajowych ośrodkach naukowych, jak też w firmach produkujących testy diagnostyczne, prowadzone są badania w zakresie technologii i produkcji nowych zestawów diagnostycznych (3). Trzeba mieć na uwadze, że niektóre $\mathrm{z}$ dostępnych testów mogą mieć zastosowanie tylko w badaniach naukowych (RUO, research use only), a tylko te posiadające certyfikat dla wyrobów do diagnostyki in vitro (CE- IVD) zgodnie $\mathrm{z}$ prawem mogą być używane w rutynowych badaniach diagno- 


\section{RAPID IMMUNOCHROMATOGRAPHIC \\ "CASSETTE" TESTS FOR DETECTION OF ANTIBODIES AGAINST SARS-CoV-2 VIRUS}

About 190 commercial serological tests are currently (April 19, 2020) available on the market to screen for specific antibodies to the SARS-CoV-2 (12). Most of them are so-called rapid "cassette" tests based on lateral-flow immunochromatography (lateral-flow, LFIA). The principle of these tests is the reaction of serum, plasma or whole blood antibodies present in the sample with labeled, e.g. gold particles, virus antigen (Figure 2). The resulting complex migrates through the nitrocellulose membrane under the action of capillary forces and is finally captured by membrane-attached human immunoglobulin antibodies, forming a red line. The advantage of these tests is the simplicity of implementation (no additional reagents or equipment to read the results are needed) and a very short time to obtain the result (usually 10-30 minutes). A positive result is indicated by the appearance of test lines and a control line. In case of the absence of a control line, the test should be repeated (Figure 3) $(17,18)$.

These tests can be performed in any outpatient clinic or even in field conditions. In many countries, including the USA, Germany, Republic of Korea, China, these tests have even been used in special mobile "Drive-Thru" sampling points, where material for testing from high-risk patients is taken. Currently, "Drive-Thru" or "Go-Thru" tests in Poland are stycznych. Najwięcej testów zostało opracowanych w Chinach, w Korei Południowej i USA. Zestawy diagnostyczne produkowane są też przez firmy w innych krajach $(3,12)$.

\section{SZYBKIE IMMUNOCHROMATOGRAFICZNE TESTY „KASETKOWE” WYKRYWAJĄCE PRZECIWCIAŁA PRZECIW WIRUSOWI SARS-CoV-2}

Obecnie dostępnych jest na rynku około 190 (stan na dzień 19 kwietnia 2020 r.) serologicznych testów komercyjnych służących do poszukiwania swoistych przeciwciał dla wirusa SARS-CoV-2 (12). Przeważająca większość są to tzw. szybkie testy „kasetkowe” oparte na technice immunochromatografii z przepływem bocznym (lateral-flow, LFIA). Zasada działania tych testów polega na reakcji obecnych w próbce surowicy, osocza bądź pełnej krwi przeciwciał ze znakowanymi, np. cząsteczkami złota, antygenami wirusa (Ryc. 2). Powstały kompleks migruje przez membranę nitrocelulozową pod wpływem działania sił kapilarnych i jest ostatecznie wychwytywany przez przyczepione na membranie przeciwciała dla ludzkich immunoglobulin, tworząc czerwoną linię.

Zaletą tych testów jest prostota wykonania (nie są potrzebne żadne dodatkowe odczynniki czy też wyposażenie do odczytu wyniku) oraz bardzo krótki czas uzyskania wyniku (zazwyczaj 10-30 minut). O wyniku dodatnim świadczy pojawienie się linii testowych oraz linii kontrolnej. W przypadku braku linii kontrolnej
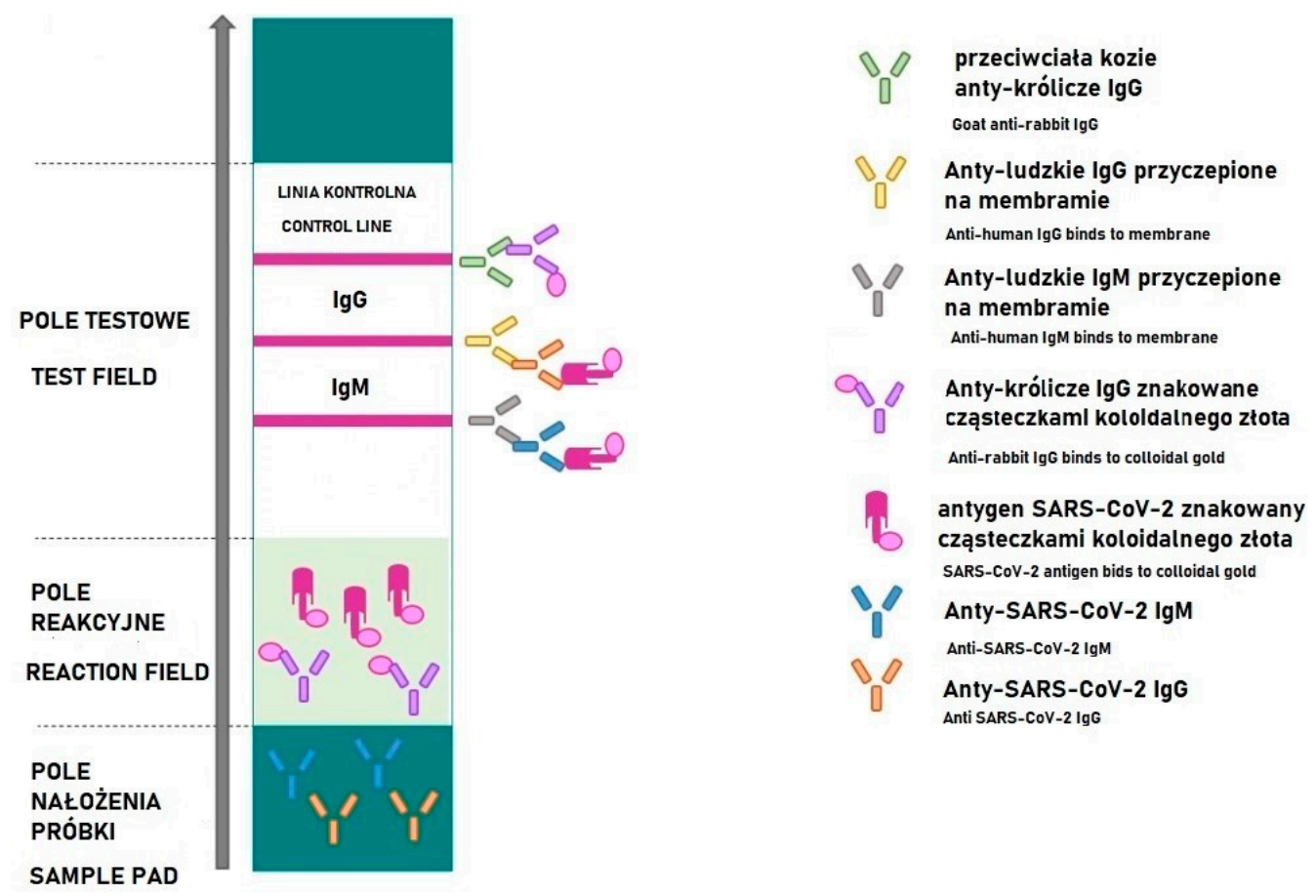

Figure 2. The principle of rapid immunochromatographic test (17)

Rycina 2. Zasada działania szybkiego testu immunochromatograficznego (17) 


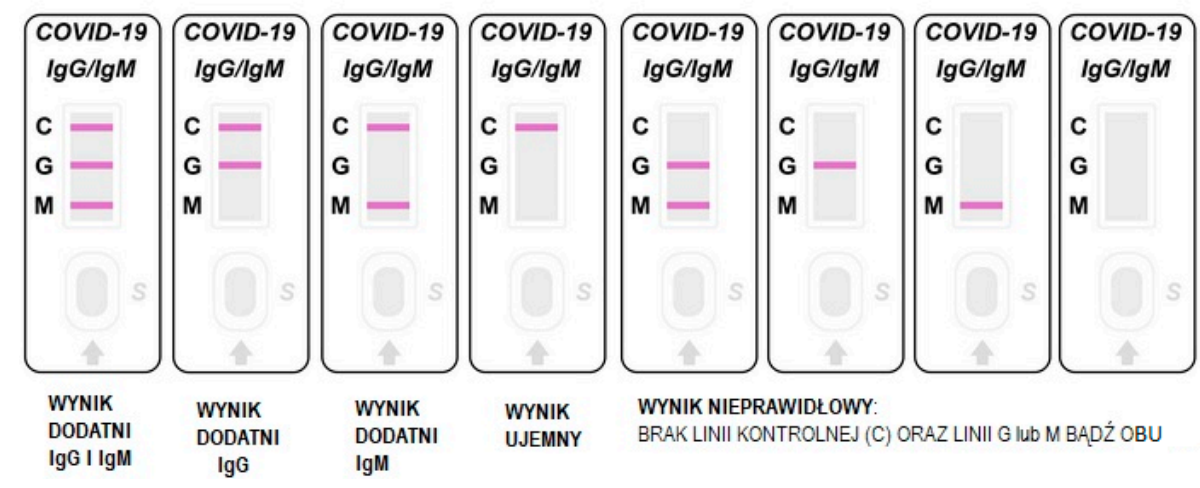

Figure 3. Visualization of reading results in a fast immunochromatographic COVID-19 IgG/IgM Rapid Test Kit manufactured by Abbexa Ltd. (19)

Rycina 3. Wizualizacja odczytu w szybkim immunochromatograficznym teście „kasetkowym” COVID-19 IgG/IgM Rapid Test Kit firmy Abbexa Ltd. (19)

performed, among others by Diagnostyka Sp. z o.o. in Lodz, Cracow, Poznan, and Warsaw.

It should be borne in mind that currently there are no results of usefulness of these tests for routine diagnosis conducted by scientific, independent research. For some tests, only manufacturer's data is available, which usually indicates at a very high sensitivity and specificity of the kits produced. Thus, rapid tests should be validated before being introduced to routine diagnosis. The advisability of such validation is evidenced by the latest information from some European countries indicating a very low correlation of the results obtained in these tests with the results of tests carried out by RT-PCR $(3,20)$. Selected "cassette" immunochromatographic tests of various companies, together with their short characteristics, are presented in Table II. badanie należy powtórzyć (Ryc. 3) $(17,18)$. Badania te mogą być wykonane w każdym ambulatorium szpitalnym czy nawet w warunkach terenowych. W wielu krajach, m.in. w USA, Niemczech, Korei Południowej czy Chinach testy te znalazły zastosowanie nawet w specjalnych mobilnych punkach pobrań typu „Drive -Thru", w których pobierany jest materiał do badania od pacjentów podwyższonego ryzyka. Obecnie badania „Drive-Thru” lub „Go-Thru” w Polsce wykonywane są m.in. przez Laboratoria Medyczne Diagnostyka Sp. z o.o. w Łodzi, Krakowie, Poznaniu oraz w Warszawie.

Trzeba mieć na uwadze, że obecnie nie ma wyników badań naukowych przeprowadzonych przez niezależne zespoły badawcze oceniających przydatność tych zestawów do badań diagnostycznych. W przypadku niektórych testów dostępne są jedynie dane producenta, określające zazwyczaj na bardzo wysokim poziomie, czułość i swoistość diagnostyczną wyprodukowanych zestawów. Tak więc, szybkie testy, przed wprowadzeniem do rutynowej diagnostyki $\mathrm{w}$ danym kraju, powinny zostać wcześniej zwalidowane. O celowości takiego działania świadczą ostatnie informacje z niektórych państw europejskich mówiące o bardzo niskiej korelacji wyników uzyskanych w tych testach z wynikami badań przeprowadzonych metodą RT-PCR $(3,20)$. Wybrane szybkie „kasetkowe” testy immunochromatograficzne różnych firm, wraz z ich krótką charakterystyką, zaprezentowano w Tabeli II. 


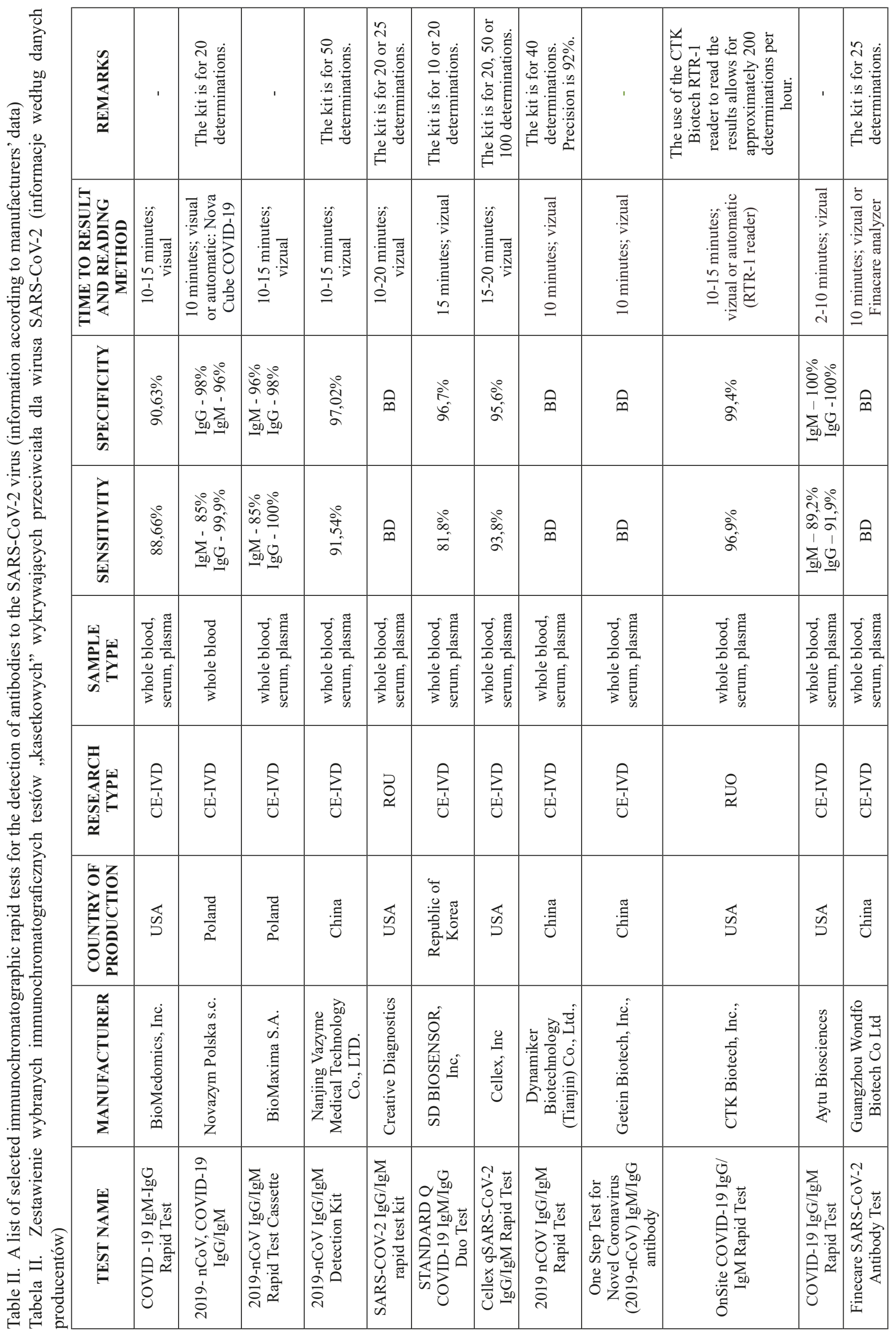




\begin{tabular}{|c|c|c|c|c|c|c|c|c|c|c|c|c|}
\hline ' & \multicolumn{2}{|c|}{ 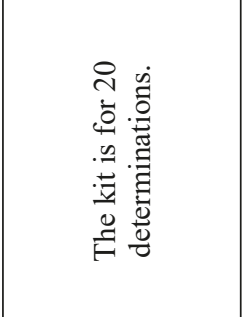 } & 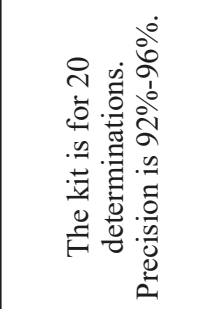 & 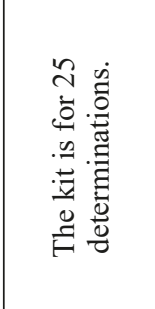 & , & 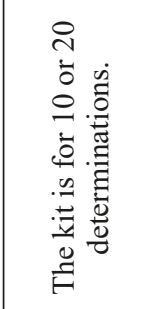 & 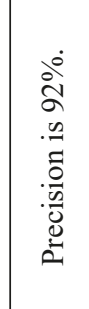 & 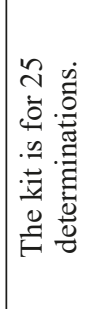 & 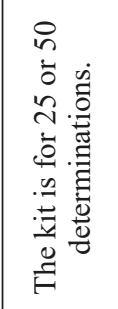 & 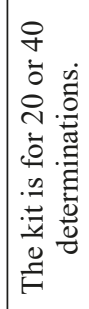 & & \\
\hline 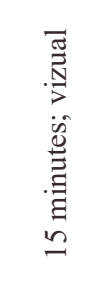 & \multicolumn{2}{|c|}{ 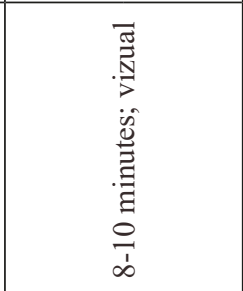 } & 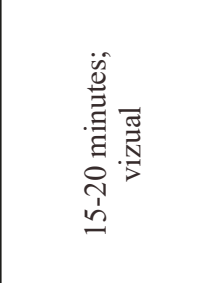 & 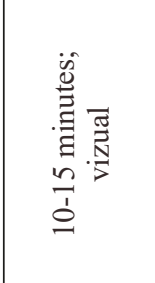 & 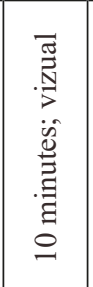 & 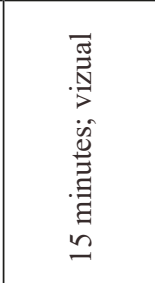 & 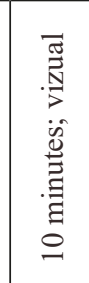 & 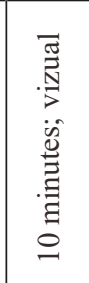 & 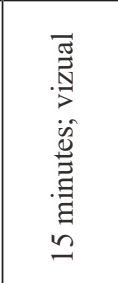 & คิ & ติ & \\
\hline 用 & 用 & ๓ิ & 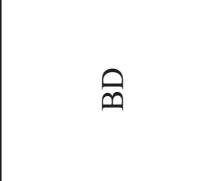 & ๓ิ & 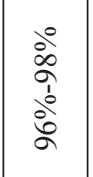 & $\begin{array}{l}\stackrel{\circ}{ } \\
\text { مे }\end{array}$ & 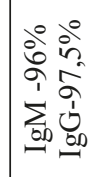 & 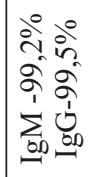 & 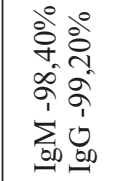 & ๓ิ & 用 & \\
\hline ติ & 用 & 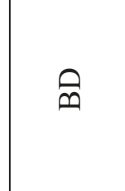 & 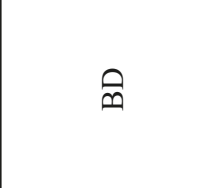 & ติ & $\begin{array}{l}\grave{\hat{े}} \\
\text { aे̀ } \\
\text { aे }\end{array}$ & $\begin{array}{l}\dot{0} \\
\text { oे }\end{array}$ & 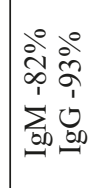 & 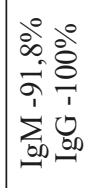 & 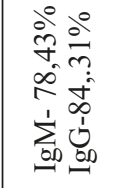 & कิ & ติ & 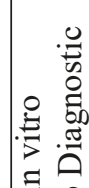 \\
\hline 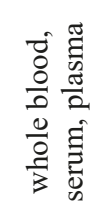 & \multicolumn{2}{|c|}{ 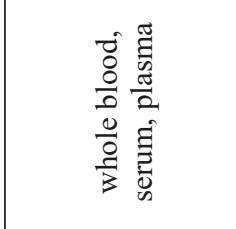 } & 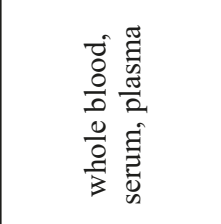 & 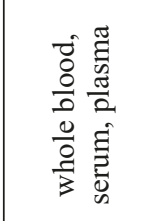 & 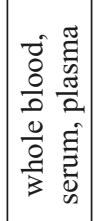 & 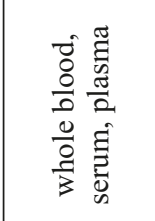 & 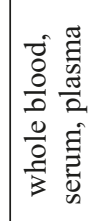 & 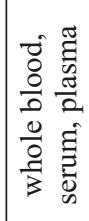 & 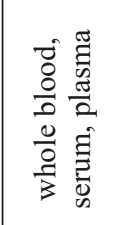 & 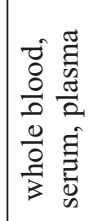 & 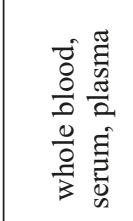 & 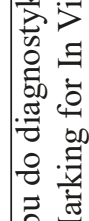 \\
\hline$\sum_{\substack{1 \\
\text { 季 }}}^{\theta}$ & \multicolumn{2}{|c|}{$\sum_{\substack{1 \\
\text { 崩 }}}^{0}$} & $\sum_{\substack{1 \\
\text { 秀 }}}^{\theta}$ & $\sum_{\substack{1 \\
\text { 秃 }}}^{\theta}$ & $\sum_{\substack{1 \\
\text { 季 }}}^{\theta}$ & $\sum_{\substack{1 \\
\text { 崩 }}}^{P}$ & $\sum_{\substack{1 \\
\mathrm{~S}}}^{\theta}$ & $\sum_{\substack{1 \\
\text { 皃 }}}^{2}$ & $\sum_{\substack{1 \\
\text { ț }}}^{0}$ & 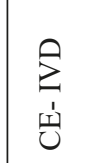 & $\sum_{\substack{1 \\
\mathrm{~d}}}^{\ominus}$ & 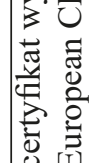 \\
\hline 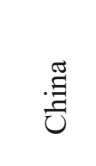 & \multicolumn{2}{|c|}{ 芯 } & $\vec{n}$ & 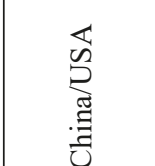 & 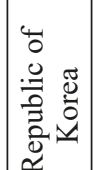 & 肎 & $\begin{array}{l}\text { 口. } \\
\text { 总 } \\
\text { : } \\
\text { : }\end{array}$ & 苟 & 节 & 节 & 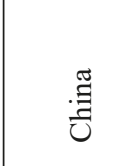 & 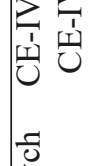 \\
\hline 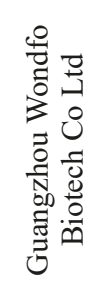 & \multicolumn{2}{|c|}{ 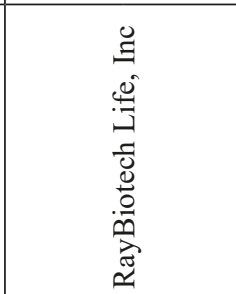 } & 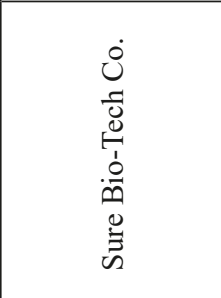 & 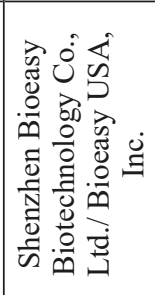 & 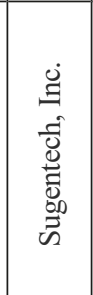 & 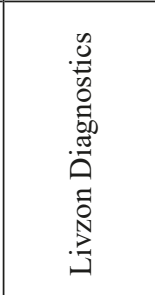 & 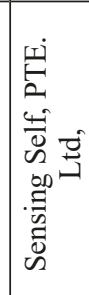 & 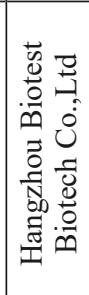 & 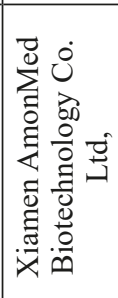 & 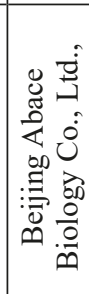 & 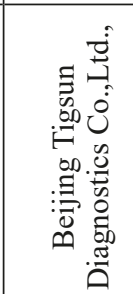 & 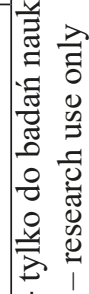 \\
\hline 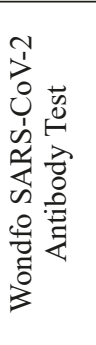 & 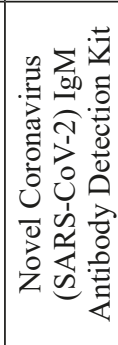 & 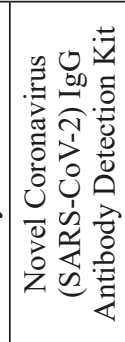 & 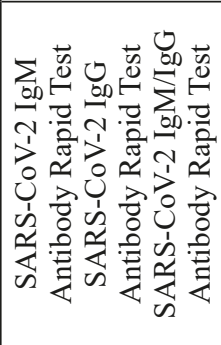 & 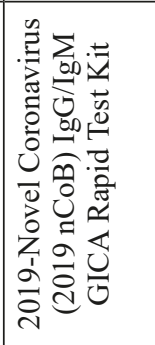 & 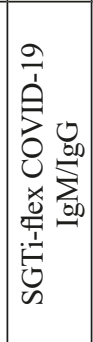 & 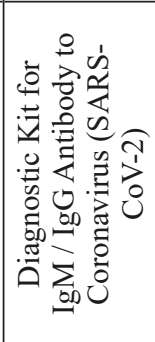 & 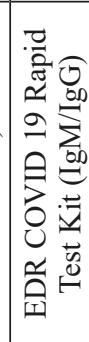 & 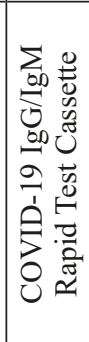 & 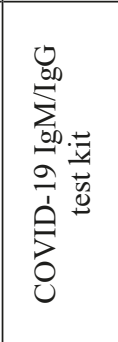 & 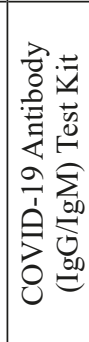 & 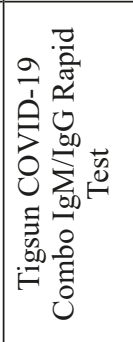 & 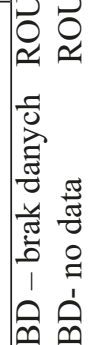 \\
\hline
\end{tabular}




\section{CHEMILUMINESCENT TESTS (CLIA) FOR DETECTION OF ANTIBODIES AGAINST SARS-CoV-2 VIRUS}

Another analytical method for detecting antibodies that has also been used to detect antibodies against COVID-19 is chemiluminescence (CLIA). In chemiluminescent immunoassay, the reaction indicator may be a luminophore marker or enzyme marker. The time to obtain a result usually does not exceed 30 minutes, however, to perform tests using this method an advanced analytical platform or analyzer is necessary (21). An example of such a test is the Maglumi CLIA kit from Snibe Diagnostic (China), in which ABEI (new isoluminol) molecules were used for labeling. Currently, several diagnostic centers in Poland already have equipment that allows testing using Maglumi 2019-nCoV reagents.

The main advantages of automated COVID-19 tests based on CLIA analyzers compared to fast LFIA tests are higher sensitivity, very high sample throughput: up to 180 tests per hour and high speed of obtaining results - the first results are obtained after 12 or 17 minutes depending on the type of analyzer $(21,22,23)$. A similar CLIA system was launched by Diazyme Laboratories Inc., offering the tests: Diazyme DZ-Lite SARS-CoV-2 IgG and SARSCoV-2 IgM CLIA, requiring Diazyme DZ-Lite 3000 Plus analyzer. The throughput of this system is about 50 determinations per hour. We get the first results after about 30 minutes. The disadvantage is the inactivation of the test sample at $56^{\circ} \mathrm{C}$ for 30 minutes (13). However, the results obtained using serological tests should be confirmed by RT-PCR testing.

Another CLIA test is the SARS-CoV-2 IgM/IgG kit from Shenzhen YHLO Biotech Co., Ltd (China). Two SARS-CoV-2 antigens, a nucleocapsid $(\mathrm{N})$ protein and a peak protein (S) were used. The tests were conducted on a fully automated chemiluminescent analyzer iFlash3000 from Shenzhen. Comparing the results of serological tests to the "gold standard", which is RT-PCR, the authors rated the test sensitivity in both classes of antibodies at over $90 \%$ (24). In the group of 43 patients with SARS-CoV-2 infection in the acute phase of the disease, IgG class antibodies were found in $88.9 \%$ and $\operatorname{IgM}$ class in $48.1 \%$ of cases. The authors noted that over time, the level of IgM antibodies decreased, and the IgG class antibodies increased, which then stabilized at a high level. Examples of rapid chemiluminescent tests (CLIA) are shown in Table III.

\section{TESTY CHEMILUMINESCENCYJNE (CLIA) WYKRYWAJACE PRZECIWCIAŁA PRZECIW WIRUSOWI SARS-CoV-2}

Inną metodą analityczną wykrywania przeciwciał, wykorzystaną również do wykrywania przeciwciał przeciw COVID-19 jest chemiluminescencja (CLIA). W immunologicznych testach chemiluminescencyjnych wskaźnikiem reakcji może być marker luminoforowy lub enzymatyczny. Czas uzyskania wyniku zwykle nie przekracza 30 min., jednak do wykonania testów tą metodą niezbędna jest zaawansowana platforma analityczna lub analizator (21). Przykładem takiego testu jest zestaw Maglumi CLIA firmy Snibe Diagnostic (Chiny), w którym do znakowania użyto cząsteczek ABEI (nowego izoluminolu) (22). Obecnie kilka ośrodków diagnostycznych w Polsce posiada już sprzęt umożliwiający przeprowadzanie testów z wykorzystaniem odczynników MAGLUMI 2019-nCoV.

Głównymi zaletami zautomatyzowanych testów COVID-19 opartych na analizatorach CLIA w porównaniu z szybkimi testami LFIA jest wyższa czułość, bardzo wysoka przepustowość próbek: do 180 testów na godzinę oraz szybkość uzyskiwania wyników - pierwsze wyniki otrzymujemy już po 12 lub 17 minutach w zależności od typu analizatora $(21,22,23)$. Podobny system CLIA wprowadziła na rynek firma Diazyme Laboratories Inc., oferująca testy: Diazyme DZ-Lite SARS-CoV-2 IgG i SARS-CoV-2 IgM CLIA, które wymagają analizatora Diazyme DZ-Lite 3000 Plus. Przepustowość tego systemu to około 50 oznaczeń w ciągu godziny. Pierwsze wyniki uzyskujemy po około 30 minutach. Wadą jest konieczność inaktywacji badanej próbki w temperaturze $56^{\circ} \mathrm{C}$ przez 30 minut (13). Obie firmy zastrzegają, iż wyniki uzyskane przy użyciu testów serologicznych powinny być potwierdzone w badaniu przy użyciu metody RT-PCR.

Innym testem CLIA jest zestaw SARS-CoV-2 IgM/ IgG firmy Shenzhen YHLO Biotech Co., Ltd (Chiny). $\mathrm{W}$ teście zastosowano dwa antygeny SARS-CoV-2, bialko nukleokapsydu (N) oraz białko szczytowe (S). Badania zostały przeprowadzone na w pełni automatycznym chemiluminescencyjnym analizatorze iFlash3000 firmy Shenzhen. Porównując wyniki badań serologicznych do „złotego standardu”, jakim są badania genetyczne, autorzy ocenili czułość testu w obydwu klasach przeciwciał na ponad $90 \%$ (24). W grupie 43 osób z zakażeniem SARS-CoV-2 w ostrej fazie choroby przeciwciała klasy IgG wykryto u 88,9\%, natomiast klasy IgM u 48,1\%. Autorzy zauważyli, że wraz z upływem czasu spadał poziom przeciwciał klasy IgM i wzrastał przeciwciał klasy IgG, który następnie stabilizował się na wysokim poziomie. Przykładowe szybkie testy chemiluminescencyjne (CLIA) przedstawiono w Tabeli III. 


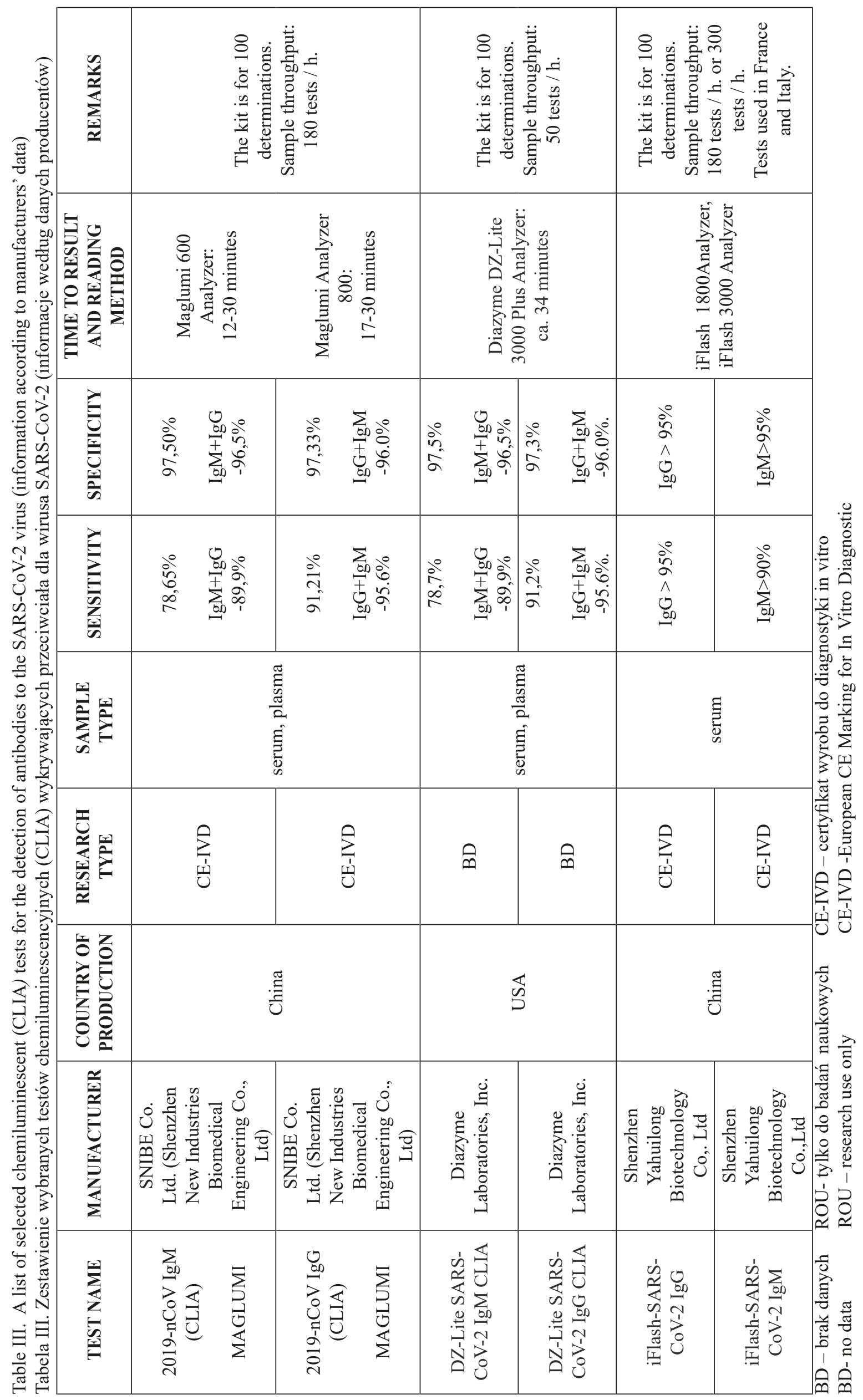




\section{ENZYME-LINKED ELISA KITS FOR DIAGNOSIS OF ANTIBODIES AGAINST SARS-CoV-2 VIRUS}

In serodiagnosis of viral infections, enzymelinked ELISA kits for detection of specific IgA, IgG and IgM antibodies in the serum samples are commonly used $(3,8,12)$. These tests have also been adapted, both by commercial companies and by individual research teams (in-house tests), to search for antibodies against SARS-CoV-2 virus. Compared to rapid immunochromatographic tests, ELISA tests are generally characterized by much higher sensitivity and the ability to simultaneously determine antibodies in a large number of clinical samples. However, due to the technical complexity and time needed to perform the test, they can only be performed in a diagnostic laboratory.

An example of a commercial ELISA is a kit developed by Euroimmun for screening for IgG and IgA antibodies for SARS-CoV-2 (25). In this ELISA kit, the wells of the plate were coated with a recombinant SARS-CoV-2 structural protein (S1 domain). The diagnostic sensitivity of the ELISA kit was determined by testing 9 samples from 8 European patients with COVID-19 infection confirmed by RTPCR, including 4 samples obtained at an earlier stage of infection (two positive results in $\operatorname{IgA}$ and one in $\mathrm{IgG}$ ) and on 5 samples obtained at a later stage of infection (five positive results in IgA and four positive in IgG). The specificity of the ELISA was performed on the sera of patients in which various antiviral antibodies, rheumatoid factors and other antibodies were found, as well as in patients with acute bacterial pneumonia. Of the total number of 200 samples, 15 sera were positive in the Anti-SARSCoV-2 (IgA) ELISA giving a specificity of the test of $92.5 \%$. In the case of IgG antibodies, only 3 sera from the control group were positive, which allowed the test specificity to be determined at $98.5 \%$. Examples of commercial ELISA kits for COVID-19 diagnostics are shown in Table IV.

There is very little information in the available literature regarding the results of serological tests carried out with commercial kits and in-house ELISA tests on a representative group of patients by independent research teams. The results of several tests using such ELISA tests are listed below.

1. Enzyme linked immunosorbent assay (ELISA) - kit by Beijing Wantai Biological Pharmacy Enterprise Co., Ltd. (China)

The results, obtained using this commercial ELISA kit, have been described by Zhao et al. (26). An indirect ELISA assay with recombinant protein antigen (nucleoprotein) was used to screen for $\operatorname{IgG}$

\section{TESTY IMMUNOENZYMATYCZNE ELISA W DIAGNOSTYCE PRZECIWCIAŁ PRZECIW WIRUSOWI SARS-CoV-2}

W serodiagnostyce zakażeń wirusowych powszechnie wykorzystuje się zestawy immunoenzymatyczne ELISA, przy użyciu których można oznaczyć w badanych próbkach surowicy poziom swoistych przeciwciał klasy $\operatorname{IgA}, \operatorname{IgG}$ i $\operatorname{IgM}(3,8,12)$. Testy te zostały przystosowane, zarówno przez firmy komercyjne jak też przez poszczególne zespoły badawcze (testy-in-house), do poszukiwania przeciwciał przeciw wirusowi SARS-CoV-2. W porównaniu do szybkich testów immunochromatograficznych testy ELISA z zasady charakteryzują się znacznie wyższą czułością oraz możliwością jednoczesnego oznaczenia przeciwciał w dużej liczbie próbek klinicznych. Ze względu jednak na techniczne skomplikowanie oraz czas potrzebny na przeprowadzenie testu mogą być one wykonywane jedynie w laboratorium diagnostycznym.

Przykładem komercyjnego testu ELISA jest zestaw opracowany przez firmę Euroimmun do poszukiwania przeciwciał klasy IgG i IgA dla wirusów SARS-CoV-2 (25). W zestawie tej firmy studzienki płytki zostały opłaszczone rekombinowanym białkiem strukturalnym (domena S1) SARS-CoV-2. Czułość diagnostyczna zestawu ELISA została określona poprzez badanie 9 próbek od 8 europejskich pacjentów z zakażeniem COVID-19 potwierdzonym badaniem RT-PCR, w tym na 4 próbkach uzyskanych we wcześniejszym etapie zakażenia (uzyskano dwa dodatnie wyniki w IgA i jeden w $\operatorname{IgG}$ ) oraz na 5 próbkach uzyskanych w późniejszym etapie zakażenia (uzyskano pięć dodatnich wyników w IgA i cztery w $\operatorname{IgG}$ ). Swoistość testu ELISA została przeprowadzona na surowicach pacjentów, w których stwierdzono obecność różnych przeciwciał przeciwwirusowych, czynników reumatoidalnych i innych przeciwciał, a także u pacjentów z ostrym bakteryjnym zapaleniem pluc. W teście ELISA Anty-SARS-CoV-2 (IgA) z ogólnej liczby 200 próbek 15 surowic było dodatnich, dając swoistość tego testu na poziomie $92,5 \%$. W przypadku przeciwciał klasy IgG tylko 3 surowice były dodatnie, co pozwoliło na określenie swoistości testu na 98,5\%. Przykładowe komercyjne zestawy ELISA przeznaczone do diagnostyki COVID-19 przedstawiono w Tabeli IV.

$\mathrm{W}$ dostępnym piśmiennictwie jest bardzo niewiele informacji dotyczących wyników badań serologicznych przeprowadzonych zestawami komercyjnymi oraz testami in-house ELISA na reprezentatywnej grupie osób chorych przez niezależne zespoły badawcze. Poniżej zestawiono wyniki kilku badań uzyskanych przy wykorzystaniu takich właśnie testów ELISA.

1. Enzyme linked immunosorbent assay (ELISA) - zestaw firmy Beijing Wantai Biological Pharmacy Enterprise Co.,Ltd. (Chiny) 


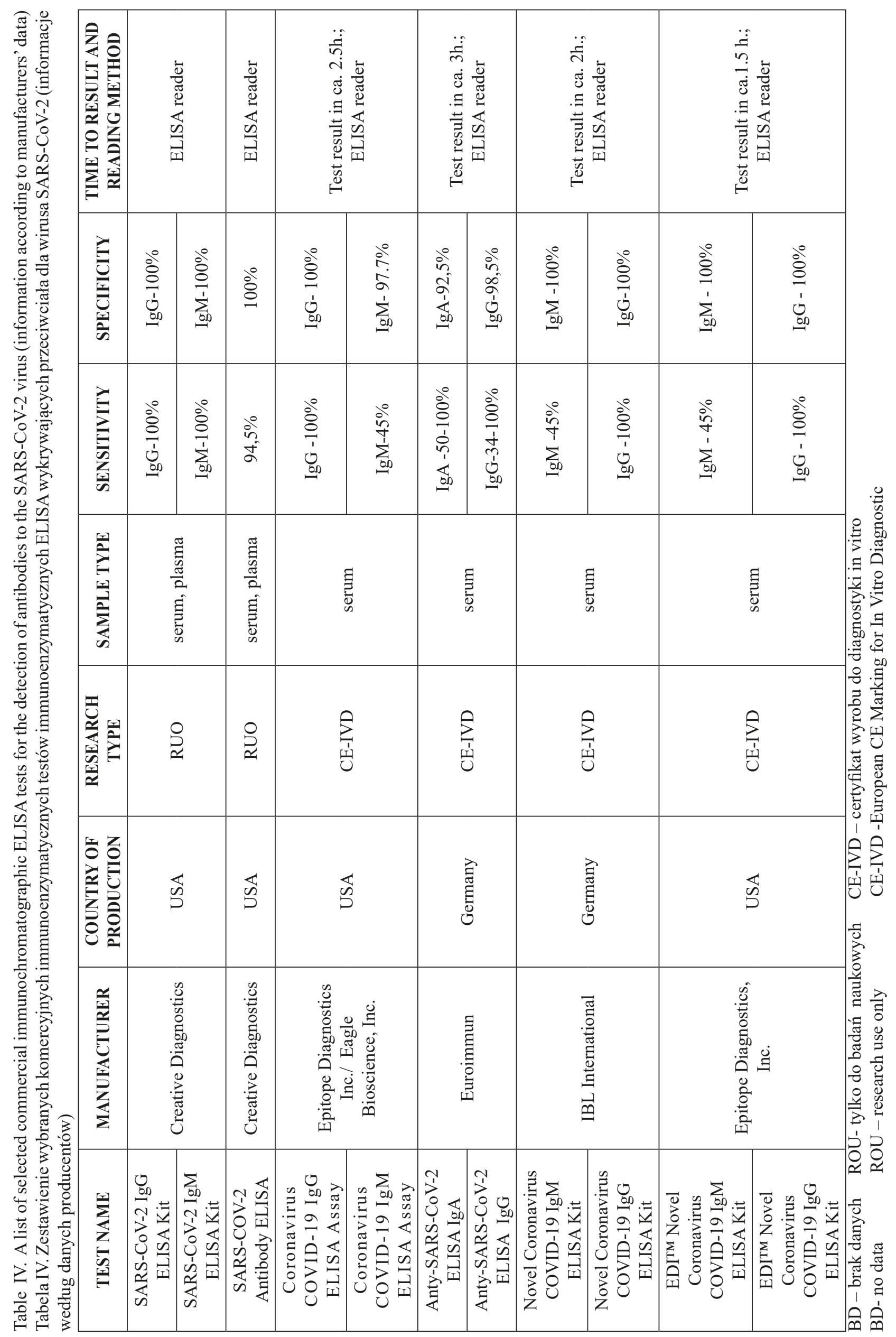


antibodies. For analysis of IgM antibodies a double sandwich assay using recombinants containing the RBD domain of SARS-CoV-2 conjugated with horseradish peroxidase was used ( $\mu$-chain capture). According to the manufacturer, the specificity of the test in both classes of immunoglobulins is over $98 \%$. The main subject of the present study was 535 plasma samples obtained from 173 patients with infection confirmed by genetic tests. Overall, the IgG antibodies were found in $64.7 \%(112 / 173)$ and $\operatorname{IgM}$ in $82.7 \%(143 / 173)$ of patients. The authors also analyzed in their studies the dynamics of antibodies in relation to the results of genetic tests. In the early phase of the disease, within the first 7 days after the onset of clinical symptoms, the RNA test had the highest sensitivity $(66.7 \%)$, while the ELISA test had the lowest $(38.3 \%)$. In samples obtained on the 8-14th day from the beginning of the disease, antibodies IgM and $\operatorname{IgG}$ were detected in $73.5 \%$ and $54.1 \%$, respectively, while RNA only in $54.0 \%$ of cases. In the late phase of the disease (day 15-39 from the onset of clinical symptoms) the sensitivity of the ELISA test in the authors' studies was $94.3 \%$ in the IgM class and $79.8 \%$ in the IgG class, while the sensitivity of genetic tests decreased to $45.5 \%$. According to the authors, serological tests may be useful for clinically diagnosed patients, whose infection has not been confirmed by genetic tests, and in asymptomatic close contacts in quarantine. In the latter case, patients with a positive serological tests should be considered asymptomatic carriers and the RNA should be tested.

In addition, the results of this study indicate a positive correlation between antibody titers and clinical severity. Thus, high levels of antibodies can be considered as an important indicator of the risk of severe disease, regardless of age, gender or comorbidities (26).

2. Enzyme linked immunosorbent assay (ELISA) Zhuhai Lizhu Reagent Co., Ltd. (China) kit and rS -based ELISA kit from Beijing Hotgen Biotech Co. Ltd. (China).

Liu et al. (27) analyzed the level of specific antibodies in patients with SARS-CoV-2 using two commercial ELISA kits: Lizhu and Hotgen. In the commercial kit of Lizhu for searching for IgM antibodies, the manufacturer coated the plate with monoclonal mouse antibodies for human IgM ( $\mu$-chain). After incubation with the sera and washing the wells of the plate, the SARSCoV-2 rN protein conjugated with horseradish peroxidase was then added as a specific antigen. In the case of searching for IgG antibodies, the plate was coated directly with $\mathrm{rN}$ protein. In the
Wyniki badań serologicznych uzyskanych przy zastosowaniu tego komercyjnego zestawu ELISA zostały opisane przez Zhao i wsp. (26). Do poszukiwania przeciwciał klasy IgG zastosowano pośredni test ELISA firmy Beijing Wantai Biological Pharmacy Enterprise Co., Ltd. z rekombinowanym antygenem białkowym (nukleoproteina) natomiast do przeciwciał klasy IgM ( $\mu$-chain capture) podwójny test kanapkowy z użyciem rekombinantów zawierających domenę RBD wirusa SARS-CoV-2 sprzężonych z peroksydazą chrzanową. Według producenta swoistość testu w obydwu klasach immunoglobulin wynosi ponad $98 \%$. Głównym przedmiotem prezentowanych badań było 535 próbek plazmy uzyskanej od 173 pacjentów z objawami zakażenia potwierdzonego badaniami genetycznymi. Ogółem, obecność przeciwciał klasy IgG wykryto u 64,7\% (112/173) natomiast klasy IgM u 82,7\% (143/173) osób chorych. Autorzy przeanalizowali w swoich badaniach również dynamikę pojawiania się przeciwciał po zachorowaniu w stosunku do wyników badań genetycznych. We wczesnej fazie choroby, w ciągu pierwszych 7 dni od wystąpienia objawów klinicznych, test RNA miał najwyższą czułość (66,7\%), natomiast test ELISA najniższą (38,3\%). W próbkach materiału klinicznego uzyskanego w 8-14 dniu od początku choroby przeciwciała klasy IgM i IgG wykrywano odpowiednio w 73,5\% i 54,1\%, natomiast RNA tylko w 54,0\% przypadków. W późnej fazie choroby (15-39 dzień od początku objawów klinicznych) czułość testu ELISA w badaniach autorów wynosiła w klasie IgM 94,3\% i w klasie IgG $79,8 \%$, natomiast czułość badań genetycznych spadła do $45,5 \%$. Według autorów badania serologiczne mogą być przydatne u osób z rozpoznaniem klinicznym, u których zakażenie nie zostało potwierdzone badaniami genetycznymi oraz $\mathrm{u}$ bezobjawowych osób z bliskiego kontaktu przebywających na kwarantannie. W tym drugim przypadku osoby $\mathrm{z}$ dodatnim wynikiem badań serologicznych należy uznać za bezobjawowych nosicieli i wykonać badania na obecność RNA. Dodatkowo, wyniki badań autorów wskazują na korelację poziomu wykrywanych przeciwciał z ciężkością objawów klinicznych. Tak więc, wysoki poziom przeciwciał można uznać za istotny wskaźnik ryzyka ciężkiego przebiegu choroby, niezależnie od wieku, płci czy współistniejących chorób (26).

2. Enzyme linked immunosorbent assay (ELISA) - zestaw firmy Zhuhai Lizhu Reagent Co., Ltd. (Chiny) oraz zestaw rS -based ELISA kit firmy Beijing Hotgen Biotech Co. Ltd., (Chiny).

Liu i wsp. (27) poszukiwali swoistych przeciwciał u chorych z SARS-CoV-2 przy użyciu dwóch komercyjnych zestawów ELISA: firmy Lizhu i firmy Hot- 
Hotgen kit, recombinant S (rS) polypeptide was used as the antigen, which was applied directly to the wells of the plate. The study showed, that among 214 patients with confirmed SARS-CoV-2 infection, IgM and $\operatorname{IgG}$ antibodies were detected in $68.2 \%$ and $70.1 \%$ of patients by the Lizhu kit, and $77.1 \%$ and $74.3 \%$ of patients, respectively, by the Hotgen kit. According to the authors, the ELISA test in which the rS polypeptide was used is more sensitive for searching for IgM class antibodies, which may be associated with earlier production of antibodies in people infected with this protein (27).

3. In-house ELISA developed by Guo et al. (28) Guo et al. have developed in-house indirect ELISA for the detection of IgM, IgA and IgG antibodies for SARS-CoV-2 using purified rNPs protein at a concentration of $0.1 \mu \mathrm{g} / \mathrm{mL}$ as antigen. They determined the cut-off value as the average absorbance $\mathrm{OD}_{450}$ obtained during the examination of healthy sera increased by three standard deviations.

The tests showed the presence of antibodies, especially IgM and IgA classes, on the first day from the onset of clinical symptoms. However, 18 out of 82 subjects $(22 \%)$ with infection confirmed by genetic tests failed to detect SARS-CoV-2 antibodies in serum samples obtained in the first week of the disease. The authors found no cross-reactions with other coronaviruses except for strong cross-reactions between SARS-CoV antibodies and SARS-CoV-2 rNP antigen (28).

4. In-house ELISA developed by Zhang et al. (29).

In an indirect in-house ELISA-IgG, recombinant protein antigen of SARS-CoV-2 Rp3 was added to each well of the plate (100 ng). In-house ELISAIgM at the first stage $500 \mathrm{ng}$ of human IgM antibodies ( $\mu$-chloride) were added followed by use of specific horseradish peroxidase conjugated antigen. Test results showed a significant increase in the level of IgM and IgG antibodies in serum samples obtained five days after the first serological test. According to the authors, serological investigation may be important in the study of patients with negative results of genetic tests (29). gen. W komercyjnym zestawie firmy Lizhu, do poszukiwania przeciwciał klasy IgM producent opłaszczył płytkę monoklonalnymi mysimi przeciwciałami dla ludzkich $\operatorname{IgM}$ ( $\mu$-chain). Po inkubacji z badanymi surowicami i wypłukaniu dołków płytki, dodawano następnie jako swoisty antygen nukleokapsydowe białko rN wirusa SARS-CoV-2 sprzężone z peroksydazą chrzanową. W przypadku poszukiwania przeciwciał klasy IgG płytkę opłaszczono bezpośrednio białkiem rN. W zestawie firmy Hotgen jako antygen zastosowano rekombinowany polipeptyd S (rS), który nakładano bezpośrednio do dołków płytki.

Wśród 214 osób z potwierdzonym badaniami genetycznymi zakażeniem SARS-CoV-2 zestawem firmy Lizhu wykryto przeciwciała klasy IgM oraz IgG odpowiednio u $68,2 \%$ oraz $70,1 \%$ pacjentów natomiast zestawem firmy Hotgen odpowiednio u 77,1\% oraz $74,3 \%$ osób chorych. Według autorów, test ELISA w którym zastosowano polipeptyd $\mathrm{rS}$ jest bardziej czuły przy poszukiwaniu przeciwciał klasy IgM, co może być związane z wcześniejszą produkcją przeciwciał u osób zakażonych dla tego białka (27).

3. Test in-house ELISA opracowany przez Guo i wsp. (28) Guo i wsp. opracowali we własnym zakresie pośredni test in-house ELISA do wykrywania przeciwciał klasy IgM, IgA i IgG dla SARS-CoV-2 stosując jako antygen oczyszczone białko rNPs w stężeniu $0,1 \mu \mathrm{g} /$ $\mathrm{mL}$. Wartość cut-off ustalili jako średnią absorbancję $\mathrm{OD}_{450}$ uzyskaną podczas badania surowic osób zdrowych powiększoną o trzy odchylenia standardowe. Przeprowadzone badania wykazały obecność przeciwciał, zwłaszcza klasy IgM i IgA, już w pierwszym dniu od początku objawów klinicznych. Jak sami jednak stwierdzają, u 18 na 82 badanych $(22 \%)$ osób z zakażeniem potwierdzonym badaniami genetycznymi nie udało wykryć się przeciwciał dla SARS-CoV-2 w próbkach surowicy uzyskanych w pierwszym tygodniu choroby.

Badając z kolei swoistość opracowanego zestawu autorzy stwierdzili brak krzyżowych reakcji z innymi koronawirusami za wyjątkiem silnych krzyżowych reakcji pomiędzy przeciwciałami dla SARS$\mathrm{CoV}$ a antygenem SARS-CoV-2 rNP (28).

4. Test in-house ELISA opracowany przez Zhang i wsp. (29).

W pośredniej metodzie in-house ELISA przy poszukiwaniu przeciwciał klasy IgG do każdej studzienki płytki dodawano $100 \mathrm{ng}$ rekombinowanego białka Rp3 wirusa SARS-CoV-2 natomiast przy badaniu klasy IgM do każdej studzienki płytki dodawano najpierw 500 ng przeciwciał dla ludzkich IgM ( $\mu$ -chain) a dopiero później swoisty antygen sprzężony z peroksydazą chrzanową. Wyniki badań wykazały znaczący wzrost poziomu przeciwciał klasy $\operatorname{IgM}$ i $\operatorname{IgG}$ w próbkach surowicy uzyskanych już 


\section{SEROLOGICAL TESTS FOR DETECTION OF SARS-CoV-2 VIRUS ANTIGENS}

In addition to serological tests for detecting specific antibodies, serological tests for detecting antigens of SARS-CoV-2 are also available (Table V). They used both the technique of immunochromatography as well as enzyme-linked ELISA methods.

Functional principle of ,rapid" tests is based on the technique of immunochromatography. Antibodies directed against SARS-CoV-2 virus antigen are immobilized on membrane strip placed on the plastic plate (most often against a nucleocapsid protein $(\mathrm{N})$ or a peak protein $(\mathrm{S})$ ) in the test zone $\mathrm{T}$.

In the initial segment of this piece there is a conjugate of colloidal gold with anti-SARSCoV-2 antigens. The execution of the test is based on extraction of SARS-CoV-2 virus antigen from sample, with the use of extraction solution, and then dropping the extract on the test plate. Antigen binds with conjugate of colloidal gold with anti-SARSCoV-2 antibodies, and the antigen-antibody complex creates. Later on, the extract is moving by capillary forces to immobilized anti-SARS-CoV-2 antibodies in $\mathrm{T}$ test zone. If there is any virus SARS-CoV-2 antigen present in the tested sample, then the colorful complex of: antibody - SARS-CoV-2 antigen antibody conjugated with colloidal gold is created, and the colorful test T stripe is generated. Lack of colorful stripe in the test zone is an evidence of the absence of virus antigen in the tested sample. The extract is later moving along the plate and in the control zone the colorful control stripe $\mathrm{C}$ is generating. The presence of this control stripe ensures the proper procedure of the test and the good quality of reagents.

Research published by scientists indicates that in the case of patients with influenza, the sensitivity of "quick" tests detecting the SARS-CoV-2 antigen in the tested sample ranges from $34 \%$ to $80 \%$. Based on this information, depending on the group of patients tested, some of the patients infected with SARS$\mathrm{CoV}-2$ virus may be misdiagnosed. In addition, it was possible to obtain false-positive results due to the presence in the tested samples of antibodies or antigen other than SARS-CoV-2 virus that causes respiratory infections (31). As an example showed in the case of the COVID-19 Ag Respi-Strip test from Coris BioConcept (Belgium), there are possible cross-reactions with the SARS-CoV virus antigen. Validation of this test was performed in two reference hospitals, where 202 samples taken from patients were tested, in which the presence of SARS-CoV-2 virus genes was confirmed by RT-PCR. Based on the results obtained, it was found that the sensitivity of the COVID-19 Ag Respi-Strip test ranges between po pięciu dniach od momentu pierwszego badania. Według autorów badania serologiczne mogą mieć istotne znaczenie w badaniu osób z ujemnymi wynikami badań genetycznych wykonanych z wymazów z gardła (29).

\section{TESTY SEROLOGICZNE WYKRYWAJĄCE ANTYGENY WIRUSA SARS-CoV-2}

Oprócz testów serologicznych służących do wykrywania swoistych przeciwciał dla wirusa SARS-CoV-2 dostępne są również testy serologiczne służące do wykrywania antygenów wirusa SARS-CoV-2 (Tabela V). Zastosowano $\mathrm{w}$ nich zarówno technikę immunochromatografii (,szybkie” testy kasetkowe) jak również metody immunoenzymateczne ELISA.

Zasada działania "szybkich" testów kasetkowych oparta jest na technice immunochromatografii. Na pasek membrany umieszczony w plastikowej płytce nanoszone są przeciwciała skierowane przeciwko antygenowi wirusa SARS-CoV-2 (najczęściej przeciw białku nukleokapsydowemu (N) lub białku szczytowemu (S) W strefie testowej T. W początkowym odcinku tego paska znajduje się koniugat złota koloidalnego z przeciwciałami anty-SARS-CoV-2. Wykonanie oznaczenia polega na wyekstrahowaniu antygenu wirusa SARSCoV-2 z próbki przy użyciu roztworu ekstrakcyjnego, a następnie nakropleniu ekstraktu na płytkę testową. Antygen wiąże się z koniugatem złota koloidalnego z przeciwciałami anty- SARS-CoV-2 i tworzy się kompleks antygen-przeciwciało. Następnie ekstrakt przemieszcza się siłami kapilarnymi do unieruchomionych przeciwciał anty-SARS-CoV-2 w strefie testowej T. Jeżeli w badanej próbce obecny jest antygen wirusa SARS-CoV-2 to powstaje barwny kompleks: przeciwciało antygen SARS-CoV-2 -koniugat przeciwciała ze złotem koloidalnym i tworzy się barwny prążek testowy T. Brak barwnego prążka w strefie testowej świadczy o nieobecności antygenu wirusa w badanej próbce. Ekstrakt przemieszcza się dalej wzdłuż płytki i w strefie kontrolnej tworzy się barwny prążek kontrolny C. Obecność tego prążka świadczy o prawidłowym wykonaniu i działaniu testu oraz o dobrej jakości odczynników.

Opublikowane przez naukowców badania wskazują, że w przypadku pacjentów chorych na grypę czułość „szybkich” testów wykrywajacych w badanej próbce antygen wirusa SARS-CoV-2 waha się od $34 \%$ do $80 \%$. $\mathrm{W}$ oparciu o te informacje, w zależności od grupy badanych pacjentów, część badanych osób zakażonych wirusem SARS-CoV-2 może zostać błędnie zdiagnozowanych. Ponadto stwierdzono możliwość uzyskania wyników fałszywie dodatnich wynikających z faktu obecności w badanych próbkach przeciwciał bądź antygenu wirusa, innego niż SARS-CoV-2, wywołującego infekcje układu oddechowego. Przykładowo, w przy- 


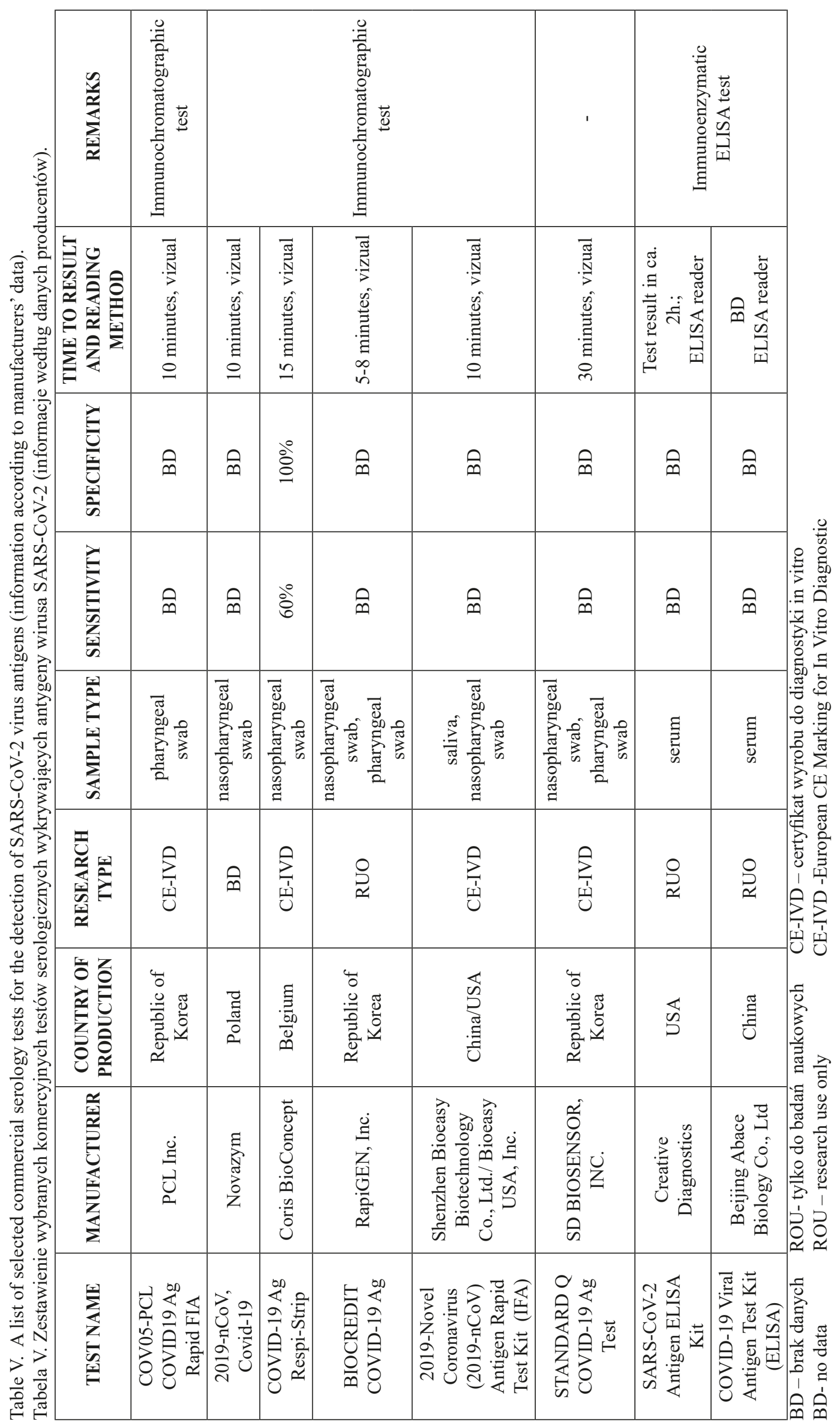


$56.14 \%-60 \%$ and the specificity between $90.2 \%$ $100 \%$. The test is recommended for screening (31).

The SARS-CoV-2 Antigen ELISA Kit from Creative Diagnostics, USA, RUO is used to quantify the level of SARS-CoV-2 recombinant nucleocapsid protein ( $\mathrm{N}$ protein) in serum (the required sample volume is $50 \mu \mathrm{l})(32)$. According to the manufacturer, there is a possibility of cross-reactions with the SARS$\mathrm{CoV}$ virus nucleocapsid protein. Such reactions have not been shown for the MERS-CoV virus N protein. It is intended for scientific research only (RUO). To perform the test and plot a standard curve, seven serial dilutions of the standard (SARS-CoV-2 Nucleoprotein Standard) should be proceed, according to the manufacturer's instructions. Therefore, a maximum of 44 samples can be researched in one test, assuming that each assay for a given sample is performed in two wells.Estimated time to complete the test is 3 hours. The lower limit of quantification (LOD) is 1 $\mathrm{ng} / \mathrm{ml} \mathrm{N}$ protein (32).

\section{SUMMARY}

A review of the available information on serological tests for the diagnosis of COVID-19 above all shows the great interest of commercial companies in the production of this type of kits. There are currently many different tests available on the market, mainly those produced in Asia, both for searching for antibodies and antigens of the SARS-CoV-2 virus. On the other hand, there is lack of reliable scientific research about the diagnostic usefulness of individual tests. Such tests should be carried out as soon as possible on a representative number of clinical specimens, obtained from patients for whom the presence of the virus was detected by genetic methods, persons with symptoms of respiratory infection caused by pathogens other than SARS-CoV-2, as well as from healthy persons. In addition to comparative assessment of individual tests, such studies will also provide the answer whether serological tests can be used in the diagnosis of patients showing acute clinical symptoms, or only for retrospective tests. Undoubtedly, the greatest usefulness in epidemiological studies will be immunoenzymatic tests detecting IgG class antibodies, which remain at an elevated level long after the end of disease.

\section{REFERENCES}

1. Przybylski M. Nowy ludzki koronawirus (SARSCoV-2). Diagnosta Laboratoryjny, Marzec 2020, 1 (58):6-13. padku testu COVID-19 Ag Respi-Strip firmy Coris BioConcept (Belgia) istnieje możliwość wystąpienia reakcji krzyżowych z antygenem wirusa SARS-CoV. Walidacja tego testu była wykonana $\mathrm{w}$ dwóch referencyjnych szpitalach, gdzie przebadano 202 próbek pobranych od pacjentów, u których potwierdzono obecność genów wirusa SARS-CoV-2 metodą RT-PCR. Na podstawie uzyskanych wyników stwierdzono, że czułość testu COVID-19 Ag Respi-Strip waha się między 56,14\% $60 \%$ a swoistość między $90,2 \%-100 \%$. Test zalecany jest do badań przesiewowych (31).

Zestaw SARS-CoV-2 Antigen ELISA Kit firmy Creative Diagnostics, USA, RUO służy do ilościowego oznaczania poziomu rekombinowanego białka nukleokapsydu (białko N) SARS-CoV-2 w surowicy (wymagana objętość próbki to $50 \mu \mathrm{l}$ ) (32). Jak podaje producent, istnieje możliwość wystąpienia reakcji krzyżowych z białkiem nukleokapsydu wirusa SARS$\mathrm{CoV}$. Nie wykazano takich reakcji w przypadku białka $\mathrm{N}$ wirusa MERS-CoV. Jest on przeznaczony tylko do badań naukowych (RUO). W celu wykonania badania i wykreślenia krzywej standardowej należy, zgodnie $\mathrm{z}$ instrukcją producenta, wykonać siedem kolejnych rozcieńczeń standardu (SARS-CoV-2 Nucleoprotein Standard). W związku z tym w jednym badaniu można zbadać maksymalnie 44 próbki, przy założeniu, że każde oznaczenie dla danej próbki wykonywane jest w dwóch dołkach. Szacunkowy czas wykonania badania to 3 godziny. Dolna granica oznaczalności testu (LOD) wynosi $1 \mathrm{ng} / \mathrm{ml}$ białka N (32).

\section{PODSUMOWANIE}

Przegląd dostępnych informacji dotyczących testów serologicznych przeznaczonych do diagnostyki COVID-19 pokazuje przede wszystkim olbrzymie zainteresowanie komercyjnych firm produkcją tego typu zestawów. Na rynku dostępnych jest aktualnie wiele różnych testów, głównie wyprodukowanych w Azji, zarówno do poszukiwania przeciwciał jak też antygenów wirusa SARS-CoV-2. Z drugiej strony brakuje rzetelnych badań naukowych mówiących o diagnostycznej przydatności poszczególnych testów. Badania takie powinny być przeprowadzone jak najszybciej na reprezentatywnej liczbie próbek materiału klinicznego uzyskanego od osób chorych, u których wykryto obecność wirusa metodami genetycznymi, osób z objawami zakażenia układu oddechowego wywołanego przez inne patogeny niż SARS-CoV-2, jak też od osób zdrowych. Poza oceną porównawczą poszczególnych testów, badania takie pozwolą również na uzyskanie odpowiedzi czy testy serologiczne mogą być stosowane w diagnostyce pacjentów wykazujących ostre objawy kliniczne czy tylko do badań retrospektywnych. Niewątpliwie, największą przydatnością w badaniach epidemiologicznych wykażą się 
2. Pyrć K. Ludzkie koronawirusy. Postępy Nauk Medycznych, XXVIII (4B), Borgis, 2015, s. 48-54.

3. Vashist SK. In Vitro Diagnostic Assays for COVID-19: Recent Advances and Emerging Trends. Diagnostics 2020, 10, 202; doi:10.3390/ diagnostics 10040202.

4. World Health Organization. (2020). Laboratory testing for coronavirus disease 2019 (COVID-19) in suspected human cases: interim guidance, 19 March 2020. World Health Organization. https:// www.who.int/publications-detail/laboratorytesting-for-2019-novel-coronavirus-in-suspectedhuman-cases-20200117

5. ECDC Case definition and European surveillance for COVID-19, as of 2 March 2020: https://www. ecdc.europa.eu/en/case-definition-and-europeansurveillance-human-infection-novel-coronavirus2019-ncov

6. Rothe C, Schunk M, Sothmann P, et al. Transmission of 2019-nCoV Infection from an asymptomatic contact in Germany. N. Engl. J. Med. 2020, 382, 970-971.

7. Bai Y, Yao L, Wei T, et al. Presumed asymptomatic carrier transmission of COVID-19. JAMA 2020. doi: 10.1001/jama.2020.2565

8. Johns Hopkins Center for Health Security. Serology testing for COVID-19. ; https://www. centerforhealthsecurity.org/resources/COVID-19/ COVID-19-fact-sheets/200228-Serology-testingCOVID.pdf.

9. Patel R, Babady E, Theel ES, et al. Report from the American Society for Microbiology COVID-19 International Summit, 23 March 2020:Value of Diagnostic Testing for SARS-CoV-2/COVID-19.

10. To KK, Tsang OT, Leung WS, et al. Temporal profiles of viral load in posterior oropharyngeal saliva samples and serum antibody responses during infection by SARS-CoV-2: an observational cohort study. Lancet Infect Dis. Marzec 2020; https://doi.org/10.1016/ S1473-3099(20)30196-1

11. Cheng MP, Papenburg J, Desjardins M, et al. Diagnostic Testing for Severe Acute Respiratory Syndrome-Related Coronavirus-2: A Narrative Reviev. Ann. Intern. Med. 2020. DOI: 10.7326/ M20-1301.

12. Fundacja FIND (Foundation for Innovative New Diagnostics); https://www.finddx.org/covid-19/ sarscov2-eval-immuno/.

13. Diazyme Laboratories Inc., Covid-19-antibodytests; http://www.diazyme.com/covid-19antibody-tests.

14. Xiao DAT, Gao DC, Zhang DS. Profile of Specific Antibodies to SARS-CoV-2: The First Report, $J$. Infect. (2020), doi: 10.1016/j.jinf.2020.03.012. testy immunoenzymatyczne wykrywające przeciwciała klasy IgG, utrzymujące się na podwyższonym poziomie długo po przechorowaniu.

15. Loeffelholz MJ, Tang YW. Laboratory diagnosis of emerging human coronavirus infections - the state of the art. Emerg. Microbes. Infect. 2020 Dec;9(1):747-756. doi: 10.1080/22221751.2020.1745095.

16. Infantino M, Damiani A, Li Gobbi F, et al. Serological Assays for SARS-CoV-2 Infectious Disease: Benefits, Limitations and Perspectives. IMAJ 2020;22:203-210.

17. CliniSciences SARS-CoV-2 (Covid-19): Diagnosis by $\mathrm{IgG} / \mathrm{IgM}$ Rapid Test. https://www. clinisciences.com/it/read/newsletter-26/sars-cov2-covid-19-diagnosis-by-2264.html.

18. Zhengtu Li, Yongxiang Yi, Xiaomei Luo, et al. Development and clinical application of a rapid IgM-IgG combined antibody test for SARS-CoV-2 infection diagnosis. J. Med. Virol., 2020.

19. Abbexa Ltd. Test COVID-19 IgG/IgM Rapid Test Kit; https://www.abbexa.com.

20. Up to $80 \%$ of Rapid COVID-19 Tests the Czech Republic Bought From China are Wrong. Prague Morning (26 marca 2020r.); https:// www.praguemorning.cz/80-of-rapid-covid-19tests-the-czech-republic-bought-from-chinaarewrong/.

21. Cinquanta L., Ethel Fontana D., Bizzaro N. Chemiluminescent immunoassay technology: what does it change in autoantibody detection? Autoimmun Highlights (2017) 8:9; doi. org/10.1007/s13317-017-0097-2.

22. Shenzhen New Industries Biomedical Engineering Co., Ltd. (Snibe Co.,Ltd) The world's first 2019-nCoV (SARS-CoV-2) CLIA Kits received CE mark; http://www.snibe.com/zh_en/en_ newsView.aspx?id=576.

23.PZ Cormay S.A. Szybkie testy wykrywające koronawirusa SARS-CoV-2; https://koronawirus. cormay.p1/.

24. Jin Y, Wang M, Zuo Z, et al. Diagnostic value and dynamic variance of serum antibody in coronavirus disease 2019. Inter. J. Infect. Dis 2020; doi: https:// doi.org/10.1016/j.ijid.2020.03.065.

25. Euroimmun. Test EUROIMMUN Anty-SARSCoV-2 ELISA IgA, IgG https://euroimmun.pl/ blog/test-euroimmun-anty-sars-cov-2-elisa-igaigg-informacje-podstawowe/.

26. Zhao J, Yuan Q, Wang H. Antibody responses to SARS-CoV-2 in patients of novel coronavirus 
disease 2019. Clin. Infect. Dis. 2020 Mar 28. pii: ciaa344.; doi: $10.1093 / \mathrm{cid} / \mathrm{ciaa344}$.

27. Liu W, Liu L, Kou G, et al. Evaluation of Nucleocapsid and Spike Protein -based ELISAs for 2 detecting antibodies against SARS -CoV2. J. Clin. Microbiol.; doi:10.1128/JCM.00461-20.

28. Guo L, Ren L, Yang S, et al. Profiling Early Humoral Response to Diagnose Novel Coronavirus Disease (COVID-19). Clin. Infect. Dis. 2020 Mar 21. pii: ciaa310.; doi: 10.1093/cid/ciaa310.

29. Zhang W, Du R, Li B, et al. Molecular and serological investigation of 2019-nCoV infected patients: implication of multiple shedding routes. Emerg. Microb. Infect. 2020, vol 9.

30. WHO. Advice on the use of point-of-care immunodiagnostic tests for COVID-19.; https:// www.who.int/news-room/commentaries/ detail/advice-on-the-use-of-point-of-careimmunodiagnostic-tests-for-covid-19.

31. Coris BioConcept. COVID-19 Ag Respi-Strip; https://v3.globalcube.net/clients/beldico/content/ medias/products/microbiology/sars-covid-19detection-test-leaflet.pdf.

32. Creative Diagnostics. ELISA SARS-CoV-2 Antigen ELISA Kit; https://www.creativediagnostics.com/SARS-CoV-2-Antigen-ELISAKit-104189-466.htm.

Received: 20.04.2020

Accepted for publication: 23.04.2020

Otrzymano: 20.04.2020 r.

Zaakceptowano do publikacji: $23.04 .2020 \mathrm{r}$.

\section{Adres do korespondencji:}

Address for correspondence:

Prof. Waldemar Rastawicki

Zakład Bakteriologii i Zwalczania Skażeń

Biologicznych

Narodowy Instytut Zdrowia Publicznego - PZH

ul. Chocimska 24,00-791 Warszawa

e-mail: wrastawicki@pzh.gov.pl

tel. +48 225421325 